\title{
LESS GROWN APPLE VARIETES IN JUICE PRODUCTION, AND THE INFLUENCE OF POLYPHENOLS AND ADDED ASCORBIC ACID ON THE JUICE QUALITY
}

\author{
Taina KuUsi and Esko Pajunen
}

\begin{abstract}
The State Institute for Technical Research, Laboratory for Food Research and Technology, Otaniemi, Helsinki
\end{abstract}

\begin{abstract}
Three apple varieties, Atlas, Erstaa, and Dolgo, were studied for their suitability for juice production and for the effect of polyphenols and added ascorbic acid on the juice quality.

The Atlas and Erstaa varieties were found to be very suitable as raw material for apple juice production. The juices of Atlas were best in quality but they were sensitive to browning while Erstaa juices were not. The juices of Dolgo were considered too tart, but with an exceptionally interesting flavour. Dolgo juices could probably be used in mixtures together with sweeter apple varieties.

Ascorbic acid could be used to prevent browning or to stop it to the desired degree and to stabilize the colour ot the juice. The second alternative was found to be better because light brownish apple juices are generally preferred.

The browning of apple juice was influenced not only by the polyphenolase activity and the polyphenol concentration but also by the type of phenolic compounds. In this respect proanthocyanidins and flavanols were most significant.
\end{abstract}

Apple juice production in Finland is very moderate compared with most European countries and Northern America. This is mainly due to the fact that most apple varieties are sensitive to the cold winter, and in addition, apples are not cultivated entirely for juice production purposes. Thus, in apple juice production the raw material may be very uneven, which easily results in variable juice quality. The situation may be improved by growing apple varieties less sensitive to winter; increased cooperation between farmers and producers would also be useful.

This investigation deals with the possibilities of using certain less known apple varieties for juice production. The juices were studied for their characteristics such as the acid and sugar content, the acid-sugar ratio, $\mathrm{pH}$, specific gravity and organoleptic properties. Special attention was paid to polyphenols and to the changes caused by these and to the effect of added ascorbic acid. 


\section{Material and methods}

The varieties studied were Atlas, Erstaa, and Dolgo, of which Atlas is an ordinary apple variety (Malus malus) of Canadian origin while Erstaa and Dolgo are hybrids of ordinary apple and crab apple $(M$. baccata). All these varieties are rather winter hardy and give rich and even yields yearly (Leskinen \& TALvia 1969).

Two samples of apple juice were prepared of each variety and to one of these ascorbic acid, $100 \mathrm{mg} / 100 \mathrm{~g}$ of apples, (cf. SKorikova \& Lyasenko 1968) was added during milling to prevent enzymatic browning. The juices were prepared on a pilot scale with a hydraulic press. After pressing the juices were pasteurized and bottled. In addition, four samples of opalescent Atlas-juices were prepared in laboratory scale and ascorbic acid was added to these juices as follows: sample $1,100 \mathrm{mg} / 100 \mathrm{ml}$ immediately after pressing, samples 2 and $3,100 \mathrm{mg} / 100 \mathrm{ml}$ one hour after pressing, whereafter sample 2 was stored closed and sample 3 open; sample 4 was a control sample without any addition.

The acid total was determined electrometrically according to AOAC and the sugar (actually soluble solids) refractometrically. The specific gravity was determined with a pycnometer. The ascorbic acid was determined by the method of RoBINson et al. (1945); amyl acetate extraction according to Erkama (1946) was used, however. Organoleptic tests were made using the scoring system of Косн (1956 a) omitting the scores based on appearance and chemical analysis. The colour of the apple juices was measured as optical density at $420 \mu \mathrm{m}$ (Johnson et al. 1969). Before the colour measurements the juices were clarified by centrifugation for one hour at $13000 \mathrm{rpm}$.

The polyphenols were extracted from the juices with hot ethyl acetate (DugGan 1967), after which they were transferred to an aqueous phase (Swain \& Hillis 1959) and concentrated for quantitative determinations. From the apples the polyphenols were extracted with boiling 90 per cent methanol. After an addition of water, extraction was continued as described for juices. The extractions and concentrations were performed in a nitrogenous atmosphere to prevent polyphenol oxidation.

The totals of the polyphenols, flavanols and proanthocyanidins (leucoanthocyanidins) were determined by the methods described by Swain \& Hillis (1959). In the first two determinations $( \pm)$-catechin was used as reference compound and in the third the "persimmon leucoanthocyanidin" curve of JosLyN \& Goldstern (1964) was used as standard. Chlorogenic acid was determined by the method of Hetr \& Lehmann (1966). Polyphenolase activity determinations were made by the method of PonTING \& JosLYN (1948).

\section{Results and discussion}

Table 1 shows the results of the juice analyses and ascorbic acid determinations. The specific gravity, total acidity, soluble solids and acid-sugar ratios increase in the order Atlas, Erstaa, and Dolgo, the values of Dolgo being considerably higher than those of Atlas and Erstaa. The addition of ascorbic acid leads to a decrease in the specific gravity and the soluble solids, and to an increase in the total acidity and the acid-sugar ratio. Furthermore, it appears that the retention of ascorbic acid is fairly good and is independent of the apple variety and the initial ascorbic acid content. It is not clear to what extent it would be possible to decrease the amount of added ascorbic acid necessary for the prevention of browning while leaving the usually desired ascorbic acid level $(35 \mathrm{mg} / 100 \mathrm{ml})$ 
Table 1. Results of juice analyses and ascorbic acid determinations.



1) Calculated on the basis of $\mathrm{ml} 0.1-\mathrm{n} \mathrm{NaOH}$ (first column) and per cent malic acid (second column).

(BAUERNFEIND 1958) during storage. In this case the ascorbic acid losses are assumed to be due to manufacturing because the analyses were performed within two weeks after processing. The influence of storage on ascorbic acid retention was not investigated.

In respect of their acid-sugar ratios, the Atlas and Erstaa juices can be classified as very good juices if judged by the scale suggested by KocH (1956 b) in which the acid-sugar ratio is a criterion for juice quality. The Dolgo juices have too high an acid-sugar ratio to come within the limits of the scale and can be considered too tart. Similar results were obtained in organoleptic tests.

Total scores in organoleptic tests when comparing juices from different varieties (maximum scores 16) were as follows:

$\begin{array}{lrr}\text { juices } & \begin{array}{c}\text { scores } \\ \text { average }\end{array} & \text { limits } \\ \text { Atlas } & 14.0 & 11.0-16.0 \\ \text { Erstaa } & 11.9 & 8.0-15.0 \\ \text { Dolgo } & 9.4 & 4.0-13.5\end{array}$

with added ascorbic acid

$\begin{array}{lrr}\text { Atlas } & 11.3 & 8.0-14.5 \\ \text { Erstaa } & 12.0 & 8.5-14.0 \\ \text { Dolgo } & 9.6 & 5.0-14.0\end{array}$

The Atlas and Erstaa juices were considered to be better than the Dolgo juices. However, the taste of Dolgo juice was found to be unusual but interesting. Moreover, the juices without added ascorbic acid were preferred to the juices with ascorbic acid addition as can be seen below.

Total scores in organoleptic tests when comparing juices with and without added ascorbic acid:

$\begin{array}{ccc}\text { suice } & \text { limits } \\ \text { average } & \end{array}$




$\begin{array}{lcc}\text { Atlas } & 13.0 & 8.0-16.0 \\ \begin{array}{l}\text { Atlas with } \\ \text { added ascorbic } \\ \text { acid }\end{array} & 10.9 & 6.0-15.0 \\ \text { Erstaa } & 13.5 & 10.0-15.0 \\ \begin{array}{l}\text { Erstaa with } \\ \text { added ascorbic } \\ \text { acid }\end{array} & 11.0 & \\ \begin{array}{l}\text { Dolgo } \\ \begin{array}{l}\text { Dolgo with } \\ \text { added ascorbic } \\ \text { acid }\end{array}\end{array} & 11.3 & 7.0-13.5 \\ \end{array}$

The lowest scores given here are somewhat misleading because all the juices were considered good and the scores depend on the series to be tested. Furthermore, the taste panel was not accustomed to light apple juices resulting from ascorbic acid addition. However, the light apple juices were preferred to the dark brown ones when the juices prepared in laboratory scale were tested.

The addition of ascorbic acid during milling was able to stop the initial browning. If ascorbic acid was added one hour after pressing when the juices had darkened considerably, the colour of the juice turned somewhat lighter and no more browning occurred. This lighter colour remained, irrespective of whether the juices were stored closed or open for 5 days. In this case it was thus possible to stabilize the juice colour fairly well, and the light brownish juices were in fact preferred both to the light juices (juice 1) and to the dark brown juices (juice 4).

The polyphenol content of the apples and the juices is shown in Table 2. It can be seen that the apples had a considerably higher polyphenol content than the respective juices, and the values for juices with an addition of ascorbic acid were twice as high as without added ascorbic acid. Table 2 also shows the total polyphenol losses - including losses due to manufacturing and oxidative browning - which are calculated on the basis of 55 per cent juice yield. Chlorogenic acid losses, however, are based on the initial amounts in the apples because of the high solubility of chlorogenic acid.

The greatest total losses occurred - as may be expected (Johnson et al. 1969) - in the proanthocyanidins, and after these in flavanols and the smallest in chlorogenic acid. Total losses of proanthocyanidins and flavanols were greater in the Erstaa and Dolgo juices than in the Atlas juice. This is due to the greater losses during the manufacturing in the Erstaa and Dolgo varieties, which can be seen in every group of polyphenols. The reason for the losses in Erstaa and Dolgo being so pronounced may be found in the small apple size which causes retention of polyphenolic compounds in the press cake.

The evaluation of the losses due partly to manufacturing and partly to oxidation presented in Table 2 is necessarily only approximate because it was impossible to prevent wholly the initial oxidation in the pilot scale. Some of the oxidative losses are included in the manufacturing losses. 





The oxidative losses are greatest in the Atlas juices in respect to all types of polyphenols except chlorogenic acid. This can be explained by the great polyphenolase activity in Atlas apples. The ratio of polyphenolase activity was found to be 10:6:1 in Atlas, Erstaa, and Dolgo, respectively. Moreover, the content of proanthocyanidins and flavanols the most readily oxidizable substrates for polyphenolase (VoIgt 1964; JoHnson 1969) is the highest in the Atlas juices. The second greatest losses in respect to proanthocyanidins and flavanols might be expected in Erstaa because it showed the second highest polyphenolase activity.

However, Dolgo juices had twice as high proanthocyanidin and flavanol losses as Erstaa juices. This is probably due to the greater amount of proanthocyanidins in Dolgo juices. Flavanol concentrations are almost the same in Erstaa and Dolgo juices but in Dolgo there are nevertheless greater losses, which may be due to the interference of proanthocyanidins in the flavanol determination because here, in addition to catechins, also proanthocyanidins are assayed (cf. SwaIn \& Goldstern 1964).

The chlorogenic acid losses were greatest in Erstaa juice. This may be explained by the lack of more readily oxidizable substrates leading to oxidation of chlorogenic acid (Vorgt 1963). This reaction is not so rapid and does not cause as intense a brown colour as do proanthocyanidins and catechins, as stated by Vorgt (1963). Respectively, chlorogenic acid losses in Atlas and Dolgo juices are smaller because these varieties have enough of other substrates to be oxidized.

Table 2 also shows the polyphenol content and losses of juice No. 4 prepared in the laboratory scale. It can be seen that oxidative losses increase greatly when oxidation and browning respectively are in progress.

The polyphenol losses - especially the losses of proanthocyanidins and flavanols were also found to correlate with the degree of browning measured as optical density at $420 \mu \mathrm{m}$. It is not known whether this correlation is linear because the reddish colour in Dolgo juice caused an absorption maximum at $500 \mu \mathrm{m}$ which interfered with the colour measurements at $420 \mu \mathrm{m}$.

Thus, the browning of apple juices is not only affected by the polyphenolase activity and the amount of phenolic compounds, but also by the type of polyphenols. In this respect the role of proanthocyanidins is of great importance.

A c k n o w le d gement. The authors are indebted to Professor J. Vuorinen, Agricultural Research Centre, for supplying the material used in this study.

\section{REFERENCES}

Bauernfeind, J. G. 1958. Role of Ascorbic Acid in the Browning Phenomenon of Fruit Juices. Proceedings of the Scientific Technical Commission of International Federation of Fruit Juice Producers (IFJU) I: $159-185$. Zürich.

Duggan, M. B. 1967. Identification of Plant Material by its Phenolic Content. J. Assoc. Offic. Agr. Chemists 50: $727-734$.

Erкама, J. 1946. Kolorimetrisestä C-vitamiinin määrityksestä 2,6-diklorfenolindofenolilla. Suomen Kemistilehti 19: 21-25.

Hetт, O. \& Lehmann, G. 1966. Untersuchung über den Gehalt von Chlorogensäure in Konfitüren, Marmeladen und Obstsäften. Z. Lebensm. Untersuch. Forsch. 131: 23-29. 
Johnson, G., Donnelly, B. J. \& Johnson, D. K. 1969. Proanthocyanidins as Related to Apple Juice Processing and Storage. Food Technol. 23: 1312-1316.

Joslyn, M. A. \& Goldstein, J. L. 1964. Astringency Principles, Changes in Phenolic Content in Persimmons during Ripening and Processing. J. Agr. Food Chem. 12: 511-516.

Косн, J. 1956a. Die Qualitätsbeurteilung der Süssmoste (Fruchtsäfte) nach dem DLG-PunktbewertungsSchema. Kongress Hauptbericht des IV Intern. Fruchtsaftkongr. p. 212-219. Bonn.

Kосн, J. 1956b. Neuzeitliche Erkenntnisse auf dem Gebiet der Süssmostherstellung. Frankfurt.

Leskinen, A. \& Talvia, P. 1969. Käyt. Hedelmänvilj. Helsinki.

Official Methods of Analysis of the Association of Official Agricultural Chemists (AOAC). 10 th ed. 1965. p. 316, Washington.

Ponting, J. D. \& Joslyn, M. A. 1948. Ascorbic Acid Oxidation and Browning in Apple Tissue Extracts. Arch. Biochem. 19: 47-63.

Robinson, W. B. \& Stotz, E. 1945. The Indophenol-Xylene Extraction Method for Ascorbic Acid and Modifications for Interfering Substances. J. Biol. Chem. 160: 217-225.

Sкоrikova, Yu. G. \& Lyasenko, E. P. 1968. Polifenol'nye veshchestva i kachestvo yablochnogo soka. Konservnaya i Ovoshchesushilnaya Promyshlennost 23: 11-13.

Swain, T. \& Goldstein, J. L. 1964. The Quantitative Analysis of Phenolic Compounds. in 'Methods in Polyphenol Chemistry' ed. Pridham, J. B. p. 131-146. London.

—- \& Hrllis, W. E. 1959. The Phenolic Constituents of Prunus Domestica I-II. J. Sci. Food Agr. $10: 63-68,135-144$.

Vorgt, J. 1963. Untersuchungen über Obstinhaltsstoffe im Hinblick auf Bräunungsvorgänge bei der Herstellung von Obstkonserven. Die Lebensm. - Ind. 2: 49-51.

\section{SELOSTUS}

\section{VÄHÄN TUNNETTUJEN OMENALAJIKKEIDEN SOVELTUVUUS TUOREMEHU- TUOTANNOSSA SEKÄ POLYFENOLEIDEN JA ASKORBIINIHAPON VAIKUTUS MEHUJEN LAATUUN}

Taina KuUsi ja Esko Pajunen

Valtion Teknillinen Tutkimuslaitos, Elintarviketeollisuuslaboratorio, Otaniemi, Helsinki

Tutkimuksen kohteena oli kaksi Suomessa vähän tunnettua ja talvenkestävää omenalajiketta Erstaa ja Dolgo - joiden soveltuvuutta omenatuoremehutuotannon raaka-aineeksi tutkittiin; kontrollina oli lajike Atlas. Lisäksi tutkittiin polyfenoleiden ja askorbiinihappolisäyksen vaikutusta mehujen laatuun.

Atlas- ja Erstaa-lajikkeiden todettiin soveltuvan mehutuotannon raaka-aineeksi erittäin hyvin. Atlas-mehuja pidettiin laadultaan parhaina, mutta ne ruskistuivat herkästi liikaa. Erstaa-mehut puolestaan olivat kestäviä ruskistumista vastaan. Dolgo-mehut olivat liian happamia, mutta erittäin kiintoisan makuisia, joten niillä voisi ilmeisesti olla käyttöä sekoituksissa vähähappoisten lajikkeiden kanssa.

Askorbiinihappolisäyksellä voitiin estää ruskistuminen tai pysäyttää se haluttuun vaiheeseen, jolloin jälkimmäistä vaihtoehtoa voidaan pitää parempana, koska lievästi ruskistuneita mehuja pidettiin parhaina.

Omenamehujen ruskistumiseen vaikutti polyfenolaasi-aktiivisuuden ja polyfenolipitoisuuden lisäksi myös polyfenolikoostumus, jolloin ruskistumisen kannalta tärkeimpinä yhdisteinä voidaan pitää proantosyanidiineja ja flavanoleja. 